\title{
Histological Study of the Effect of Zinc Oxide Nanoparticles on the Cardiomyocytes of Adult Male Albino Rats with Reference to the Role of Mitochondria
} Original Article

\author{
Moushira Zoheir, Amira Medwar, Amany Solaiman and Neama Elbanawany
}

Department of Histology and Cell Biology, Faculty of Medicine, Alexandria University

\begin{abstract}
Back ground: Zinc oxide nanoparticles (ZnO-NPs) are among the most commonly used metal nanoparticles and are nowadays increasingly used in food. This might increase the chances of their exposure to the human body via the oral route. The heart is an important toxic site for nanoparticles.

Aim: The aim of the current study was to investigate the possible histological changes that might accompany the oral administration of two different doses of ZnO-NPs on left ventricular cardiomyocytes of adult albino rats.

Materials and Methods: Forty-eight adult male rats were included. The animals were randomly divided into 3 main groups. Group I (Control group). Group II (ZnO-NPs group) was further subdivided randomly into subgroup IIa that were given ZnO-NPs at a dose of $100 \mathrm{mg} / \mathrm{kg}$ body weight/day. Subgroup IIb received $400 \mathrm{mg} / \mathrm{kg}$ body weight/day ZnO-NPs for 28 days. Group III (Withdrawal group), the animals of this group did not receive any treatment for four weeks after the 28 days of treatment. Specimens from the heart apex were processed for microscopic examination. Serum level of oxidative stress and cardiac makers, as well as the morphometric study (for collagen quantification and mitochondrial morphometry), were done. Results: The light and the electron microscopes revealed histological changes in the left ventricular cardiomyocytes. Changes were dose-dependent. Group II revealed some pale stained muscle fibers with pyknotic nuclei. Others showed deeply acidophilic sarcoplasm. The electron microscope examination confirmed these changes and showed focal myolysis and abnormal mitochondria. This was associated with some hyperchromatic nuclei. After withdrawal histological changes were exaggerated. Serum marker of oxidative stress and cardiac markers showed a significant increase. Mitochondrial morphometry demonstrated fragmentation.
\end{abstract}

Conclusion: The study demonstrated that oral $\mathrm{ZnO}-\mathrm{NPs}$ are associated with variable microscopic changes, which is dosedependent. These changes didn't improve after the withdrawal of the ZnO-NPs administration.

Received: 09 January 2019, Accepted: 13 March 2019

Key Words: Cardiomyocytes; microscopic structure; mitochondrial morphometry; zinc oxide nanoparticles.

Corresponding Author: Amany Solaiman, MD, Department of Histology and Cell Biology, Faculty of Medicine, Alexandria University, Egypt, Tel.: +20 1096366227, E-mail: amanysolaiman@gmail.com

ISSN: 1110-0559, Vol. 42, No. 3

\section{INTRODUCTION}

Nanotechnology is one of the key technologies of the $21^{\text {st }}$ century. With the rapid growth of nanotechnology and increasing exposure to nanoparticles (NPs), there is a need to evaluate their toxicity. Thus, nanotoxicology has emerged ${ }^{[1]}$. Metal oxide NPs belong to a family of nanomaterials that have been manufactured for both industrial and household applications. Zinc oxide nanoparticles ( $\mathrm{ZnO}-\mathrm{NPs}$ ) are highly applicable and among the most commonly used metal NPs ${ }^{[2]}$. ZnO-NPs are being used as a food additive as well as in food processing and packaging ${ }^{[3]}$. The cardiovascular system is an important toxic site of $\mathrm{NPs}^{[4]}$

So, the aim of the current study was to investigate the possible histological changes in the left ventricular cardiomyocytes of adult albino rats after receiving two different doses $\mathrm{ZnO}-\mathrm{NPs}$ and the effect of their withdrawal.
The study demonstrated histological changes. These changes didn't improve after the withdrawal of the $\mathrm{ZnO}$ NPs administration.

\section{MATERIALS AND METHODS}

\section{Chemicals}

Zinc oxide nanoparticles ( $\mathrm{ZnO}-\mathrm{NPs}$ ) with an average size of $20 \mathrm{~nm}$ were purchased from NanoTech Egypt for Photo-Electronics Company (City of 6 October, Egypt). Immediately before administration, $\mathrm{ZnO}-\mathrm{NPs}$ were dissolved in distilled water. The suspension was sonicated at $230 \mathrm{~V}$ for 2 minutes using USR3/2907 sonicator (JulaboLabortechnik, Seelbach, Germany) at room temperature.

\section{Animals}

Forty-eight adult male rats (6-8 weeks old, $200 \pm 20$ g) were included in the present work. The animals were 
kept under standard laboratory conditions of temperature and humidity and 12 hours light/dark cycle with free access to the ordinary rat food and water. Guidelines for the care and use of animals approved by the Animal House Center, Faculty of Medicine, University of Alexandria, were followed. All procedures were approved by the Ethics Committee of the Faculty of Medicine, Alexandria University.

The animals were randomly divided into 3 main groups. All animals were given the treatments by oral gavage.

Group I (Control group): included 24 rats that were further subdivided into 2 equal subgroups;

Subgroup Ia: negative control received no treatment.

Subgroup Ib: each rat received distilled water of $10 \mathrm{ml} /$ $\mathrm{kg} / \mathrm{kg}$ body weight day ${ }^{[5]}$

Group II (ZnO-NPs group): included 12 rats. It was further subdivided randomly into two equal subgroups:

Subgroup IIa: each rat received a daily dose of $100 \mathrm{mg} /$ $\mathrm{kg}$ body weight $\mathrm{ZnO}-\mathrm{NPs}$ for 28 days $^{[6,7]}$.

Subgroup IIb: each rat received a daily dose of $400 \mathrm{mg} /$ $\mathrm{kg}$ body weight $\mathrm{ZnO}-\mathrm{NPs}$ for 28 days $^{[6,7]}$.

Group III (Withdrawal group): included 12 rats that were further subdivided randomly into two equal subgroups;

Subgroup IIIa: each rat received $\mathrm{ZnO}-\mathrm{NPs}$ in the same dose as that of subgroup IIa.

Subgroup IIIb: each rat received $\mathrm{ZnO}-\mathrm{NPs}$ in the same dose as that of subgroup IIb.

The animals of subgroups IIIa and IIIb did not receive any treatment for an additional four weeks after the 28 days of treatment.

\section{METHODS}

\section{I- Characterization of the zinc oxide nanoparticles}

The prepared NPs were characterized using the following:

\section{1- Transmission electron microscope (TEM)}

TEM yields information about the size and the morphology of NPs used. Using a Jeol 2100 electron microscope (Tokyo, Japan) at the Electron Microscopy Unit, Faculty of Agriculture, Mansoura University, Egypt, the size was determined.

\section{2- Nano Zeta particle analyzer}

Using Nano Zeta particle analyzer (Malvern, UK) at the Central Laboratory, Faculty of Pharmacy, University of Alexandria, Egypt, the zeta potential (surface charge) was determined.

\section{3-X-Ray Diffraction (XRD)}

The ZnO-NPs powder was analyzed using X-ray diffractometer (Shimadzu XRD-7000, Maxima, Japan) at the Central laboratory, Faculty of Pharmacy, University of Alexandria, Egypt. The voltage and current used were 30 kilovolts and 30 milliamperes, respectively.

\section{4- Ultraviolet-visible absorption spectroscopy (UV- Vis)}

It was carried out on a UNICAM UV-Vis spectrometry model UV5-220 at the Medical Biophysics Department, Medical Research Institute, University of Alexandria, Egypt. UV-Vis spectrum shows the Surface Plasmon Resonance that depicts the size and distribution of NPs.

\section{II-Biochemical study}

\section{1- Malondialdehyde (MDA)}

MDA levels were measured as markers of oxidative stress. The MDA calorimetric assay provides a sensitive tool for detection of the MDA, by a Humalyzer junior photometer (Human Diagnostics, Germany) at the Biochemistry Department, University of Alexandria, Egypt. The MDA in the sample reacts with thiobarbituric acid (TBA) to generate MDA-TBA adduct that can be easily quantified colorimetrically $(\mathrm{OD}=532 \mathrm{~nm})^{[8]}$.

\section{2- Creatinine Kinase (CK-MB) isoenzyme}

Creatine kinase (CK) catalyzes the reversible transfer of a high-energy phosphoryl group from ATP to form phosphocreatine ( $\mathrm{PCr}$ ), which acts as an energy storage molecule, rapidly regenerating ATP at times of increased energy demand. Increase levels clearly signal muscle damage with concomitant leakage of intracellular muscle constituents into the circulation that remains high as long as the damage exists ${ }^{[9]}$.

$\mathrm{CK}$ is a biomarker and specific tool for assessing of myocardial cell injury. CK exists in two dimeric forms, Ck-MM and CK-MB. Measurement of the CK-MB (Spectrum -Diagnostic, Hannover, Germany) was done at the Biochemistry Department, University of Alexandria, Egypt.

The test principle is to use a specific antibody that inhibits the $\mathrm{M}$ subunits of $\mathrm{Ck}-\mathrm{MM}$ and $\mathrm{CK}-\mathrm{MB}$ and thus allows the determination of the $\mathrm{B}$ subunit of $\mathrm{CK}-\mathrm{MB}^{[10]}$. $\mathrm{CK}-\mathrm{B}$ is determined from the rate of NADPH formation, measured at $340 \mathrm{~nm}$ by means of hexokinase and glucose -6- phosphate dehydrogenase coupled reaction.

\section{3- Cardiac troponin- $T$ (cTnT)}

Due to the greater cardio-specificity of cTnT, it is increasingly used as diagnostic marker for myocardial cell injury, as it is released in the circulation. The more that is detected in blood, the more severe the cardiac lesion ${ }^{[11]}$. The cTnT assay (Roche Diagnostics, Mannheim, USA) was performed at Biochemistry Department, University of Alexandria, Egypt. The test employs monoclonal antibodies directed against $\mathrm{cTnT}$. 


\section{III-Histological study}

24 hours after the end of the experimental period, half of the rats of subgroup Ia and Ib together with the rats of group II were sacrificed. Rats of group III (withdrawal group) and the remaining rats of subgroups $\mathrm{Ia}$ and $\mathrm{Ib}$ were sacrificed 4 weeks after the last dose of ZnO-NPs. All animals were euthanized. Blood samples were taken from the abdominal aorta. Then samples were centrifuged at $3000 \mathrm{rpm}$ for 20 minutes to obtain sera. Samples were stored $\left(-20^{\circ} \mathrm{C}\right)$ till further use. The animals were sacrificed by decapitation after ether anesthesia (Sigma -Aldrich St. Louis, USA).

The chest of each animal was opened and the heart was rapidly excised. The heart apex of each rat, which is mostly formed by the left ventricle was dissected and cut into 2 pieces. The first piece was immediately cut into small pieces $(1 \times 1 \mathrm{~mm} 3)$ and fixed in $3 \%$ phosphate-buffered glutaraldehyde solution and processed for transmission electron microscopic study ${ }^{[12]}$. The second piece was fixed in $10 \%$ formol saline and processed to get 5-6 $\mu \mathrm{m}$ thick paraffin sections. These sections were stained with $\mathrm{H} \& \mathrm{E}$ and Masson's trichrome stains ${ }^{[13]}$ for light microscopic examination.

\section{VI- Morphometric study and Statistical analysis}

\section{1-Collagen quantification}

Semi-automated image analysis was applied ${ }^{[14]}$. From each Masson's trichrome stained section, 5 random fields for each group were selected and imaged using an objective lens magnification of 40x. ImageJ software (version $1.51 \mathrm{k}$, Wayne Rasband, National Institutes of Health, USA) was used for the analysis.

\section{2- Mitochondrial morphometric study}

To analyze mitochondrial morphology, regions containing numerous mitochondria from the electron micrographs at the magnification of 2000 were selected. Mitochondria from the edge of the micrographs were excluded. Mitochondrial measurements were obtained using Image J (version $1.51 \mathrm{k}$, Wayne Rasband, National Institutes of Health, USA) by manually tracing only clearly detectable outlines of mitochondria on the micrographs ${ }^{[15,16]}$. The followings were measured:

1. Surface area (mitochondrial size) was reported in square pixels.

2. Perimeter in pixels.

3. Surface area/perimeter ratio was then calculated.

4. The aspect ratio (AR) was computed as (major axis/ minor axis).

5. Circularity $[4 \pi$ (surface area/perimeter2)].

Data were fed to the computer and analyzed using IBM SPSS software package version 20.0 (Armonk, NY: IBM Corp). The Kolmogorov-Smirnov test was used to verify the normality of distribution. Quantitative data were described using range (minimum and maximum), mean, standard deviation and median. Differences were considered statistically significant at $p \leq 0.05$.

\section{RESULTS}

\section{I-Characterization of the prepared $\mathrm{ZnO} O \mathrm{NPs}$}

TEM showed that the particles were with an average size of $11 \pm 5 \mathrm{~nm}$ (Figure 1A and B). The Zeta potential (surface charge) of ZnO-NPs in solution was $-32 \pm 5 \mathrm{mV}$ (Figure 1C) and the XRD revealed sharpness of the peaks pattern that showed a good formation of $\mathrm{ZnO}-\mathrm{NPs}$ (Figure 1D). Finally, the UV-Vis exhibited an absorption band at $\sim 370 \mathrm{~nm}$, indicative of the formation of $\mathrm{ZnO}-\mathrm{NPs}$ (Figure 1E).

\section{II- Biochemical results}

\section{1- Malondialdehyde (MDA)}

Is considered as an indicator of lipid peroxidation. As shown in the (Hsitogram A), no significance was noticed between subgroup Ia and Ib. However, the serum level of MDA showed significant increase in group II. Furthermore, in subgroup IIb it was significantly increased as compared with subgroup IIa. In addition, MDA showed significant increase in subgroups IIIa and IIIb at $p \leq 0.05$ as compared with groups I and II.

\section{2- Serum creatinine phosphokinase isoenzyme (CK- MB)}

As shown in the (Hsitogram B), no statistical significance was noticed between subgroups $\mathrm{Ia}$ and $\mathrm{Ib}$. CK-MB level showed significance increase in group II, with the higher dose of $\mathrm{ZnO}-\mathrm{NPs}$ in subgroup IIb shows more elevation. In addition, its level showed significance increase at $p \leq 0.05$ in subgroups IIIa and IIIb as compared with groups I and II.

\section{3- Cardiac troponin- T (cTnT)}

As shown in the (Hsitogram C), the serum level of cTnT showed a significant increase in group II, with the higher dose of ZnO-NPs in subgroup IIb shows more elevation than the lower dose in subgroup IIa. In addition, the serum level showed significance increase at $p \leq 0.05$ in subgroups IIIa and IIIb as compared with groups I and II.

\section{III-Histological results}

\section{1- Light microscopic results}

\section{a- H\&E stain results}

\section{Group I (control group)}

Light microscopic examination of ventricular myocardial sections of subgroups $\mathrm{Ia}$ and $\mathrm{Ib}$, showed branching and anastomosing fibers with narrow interstitial spaces in between. Each cardiomyocyte exhibited an acidophilic sarcoplasm with centrally located vesicular nucleus (Figure 2). 
Group II (ZnO-NPs group)

\section{Subgroup IIa}

Examination revealed focal areas of pale acidophilic sarcoplasm and few muscle fibers were fragmented. Some nuclei appeared pyknotic (Figure 3).

\section{Subgroup IIb}

More extensive myocardial lesions were encountered. Multiple areas of myocytic fragmentation and widening of the interstitial spaces were frequently seen. Hypereosinophilic sarcoplasm and pyknotic nuclei were frequently encountered (Figure 4).

\section{Group III (withdrawal group)}

\section{Subgroup IIIa}

The four week period of withdrawal after administration of the low dose of ZnO-NPs was not efficient in reversing the myocardial lesions. Foci of interrupted fibers were depicted. Some cardiomyocytes exhibited pale acidophilic sarcoplasm and others show pyknotic nuclei (Figure 5)

\section{Subgroup III b}

Progressive changes were seen. Cells with pale acidophilic sarcoplasm and deeply stained nuclei were still frequently seen (Figure 6).

\section{b-Masson's trichrome stain results}

To visualize any collagen deposition between the muscle fibers Masson's trichrome stain was used.

\section{Group I (control group)}

Sections of group I (Ia and Ib), showed scanty collagen fibers in between cardiac muscle fibers (Figure 7a). On the other hand, subgroup IIa revealed only a few interstitial collagen fibers (Figure7b). Furthermore, subgroup IIb, revealed a considerable amount of collagen fibers (Figure7c). While subgroup IIIa revealed a noticeable amount of collagen fibers (Figure 7d). Those of subgroup IIIb depicted excessive deposition of collagen fibers (Figure7e).

\section{2- Electron microscopic results}

\section{Group I (control group)}

Examination of the control group revealed ventricular cardiac muscle fibers formed of cardiomyocytes. Their sarcolemma was almost straight with very minimal subsarcolemmal sarcoplasm. The sarcoplasm of cardiomyocytes revealed several longitudinally-arranged myofibrils with alternating dark and light bands. Sarcomeres were seen between two $\mathrm{Z}$ lines. Each cardiomyocyte exhibited a single oval centrally located euchromatic nucleus. Elongated mitochondria were arranged in rows between the myofibrils (Figure 8).

\section{Group II (ZnO-NPs group)}

\section{Subgroup IIa}

The arrangement and morphology of the mitochondria varied. Many mitochondria lost their arrangement in rows and they appeared aggregated in large groups. Some mitochondria showed accumulation of electron dense deposits. In addition, dilated T-tubules were depicted (Figure 9).

\section{Subgroup IIb}

Cardiomyocytes revealed more evident ultrastructural alterations. It was obvious that $\mathrm{ZnO}-\mathrm{NPs}$ at a higher dose induced more extensive myocardial changes with an elevation of the overlying sarcolemma and marked scalloping (Figure 10a). Notably, disruption and discontinuation of the sarcolemma (Figure 10b) were also encountered. Occasionally, there were multiple areas of myofibrillar interruption(Figure 10a) and loss (Figure 10 b). Many mitochondria were aggregated in groups of variable size and shape (Figure 10b). As for the nuclear changes, many nuclei exhibited irregularity, peripheralization and increased chromatin condensation (Figure 10c).

\section{Group III (Withdrawal group)}

\section{Subgroup IIIa}

Patches of myofibrillar interruption was depicted. Mitochondria showed variability in the size and shape. The nuclei appeared euchromatic (Figure 11).

\section{Subgroup IIIb}

The cardiomyocytes of this group revealed areas of myofibrillar interruption and loss (Figure 12a). Disorganized myofibrils with the accumulation of large groups of irregularly arranged intermyofibrillar mitochondria were seen (Figure 12b), some were bizarre shaped, while others appear small and rounded (Figure 12c). Shrunken peripheral heterochromatic nuclei (Figure 12a) and multiple vacuoles (Figure 12a,c) were also depicted.

\section{III- The Histo-morphometric results}

\section{1-Collagen quantification}

In group II ( $\mathrm{ZnO}-\mathrm{NPs}$ group), the mean area percentage occupied by collagen in subgroup IIa was insignificantly increased in comparison with the control group. Regarding subgroup IIb, the mean values were significantly higher than those of the control group and subgroup IIa at $p \leq 0.05$ (Hsitogram D).

For group III, the withdrawal group, the mean value of the area percentage occupied by collagen in subgroup IIIa was significantly higher compared to the control group and subgroup IIa. In addition, the mean value of the area 
occupied by collagen in subgroup IIIb was significantly higher compared to in group I, group II and subgroup IIIa at $p \leq 0.05$.

\section{2-Mitochondrial morphometric results}

\section{a-Analysis of mitochondrial surface area/perimeter ratio}

Subgroup IIa and IIb were significantly less than the control group indicating a significant mitochondrial fragmentation. For subgroup IIIa, the results were no longer significant as compared to the control group (Hsitogram E), but significantly higher than subgroup IIa at $p \leq 0.05$. This indicated that after the four week withdrawal period with the smaller dose of $\mathrm{ZnO}-\mathrm{NPs}$, mitochondria appeared to be recovering from fragmentation. For subgroup IIIb, the ratio was significantly higher compared to the control group, but not significant compared to subgroup IIb. This indicated that after the withdrawal period with the higher dose the mitochondria were unable to recover from fragmentation.

\section{b- The mitochondrial circularity}

It is an index of sphericity with a value of 1.0 indicating perfect sphere shape. Regarding subgroup IIa, average circularity was significantly increased compared to the control group which appeared elongated. For subgroup $\mathrm{IIb}$, average circularity (Hsitogram F) was even more significantly increased compared to the control group and subgroup IIa at $p \leq 0.05$. Regarding subgroup IIIa, mean circularity was significantly increased compared to the control group but was not statistically significant in comparison with subgroup IIa. The average circularity for subgroup IIIb was significantly increased compared to the control group and subgroup IIa and IIIa, but was not statistically significant compared to subgroup IIb, indicated that the mitochondria did not recover from fragmentation.

\section{c- The aspect ratio (AR; major axis/minor axis)}

It is a measure of the mitochondrial length and branching. AR has a minimum value of 1.0 when the mitochondrion is a small, perfect circle and this value increases as the mitochondrion becomes elongated. Regarding subgroup IIa, the AR was significantly decreased compared to the control group (Hsitogram G). For subgroup IIb, the AR was even more significantly decreased compared to the control group and subgroup IIa indicated that the mitochondria tended to be more fragmented. As for subgroup IIIa, the mean AR was significantly decreased compared to the control group but was not statistically significant in comparison with subgroup IIa. Moreover, the AR for subgroup IIIb was significantly decreased compared to the control group but was not statistically significant compared to subgroup IIb.
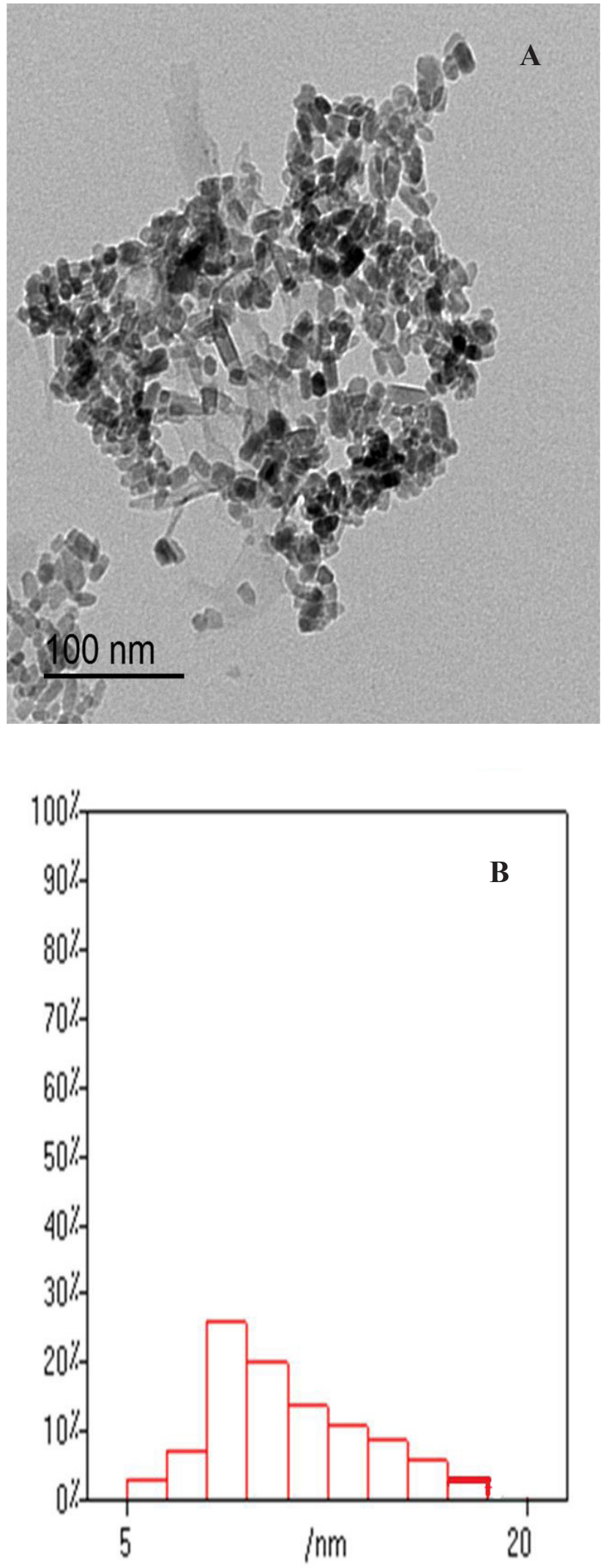

Continued 

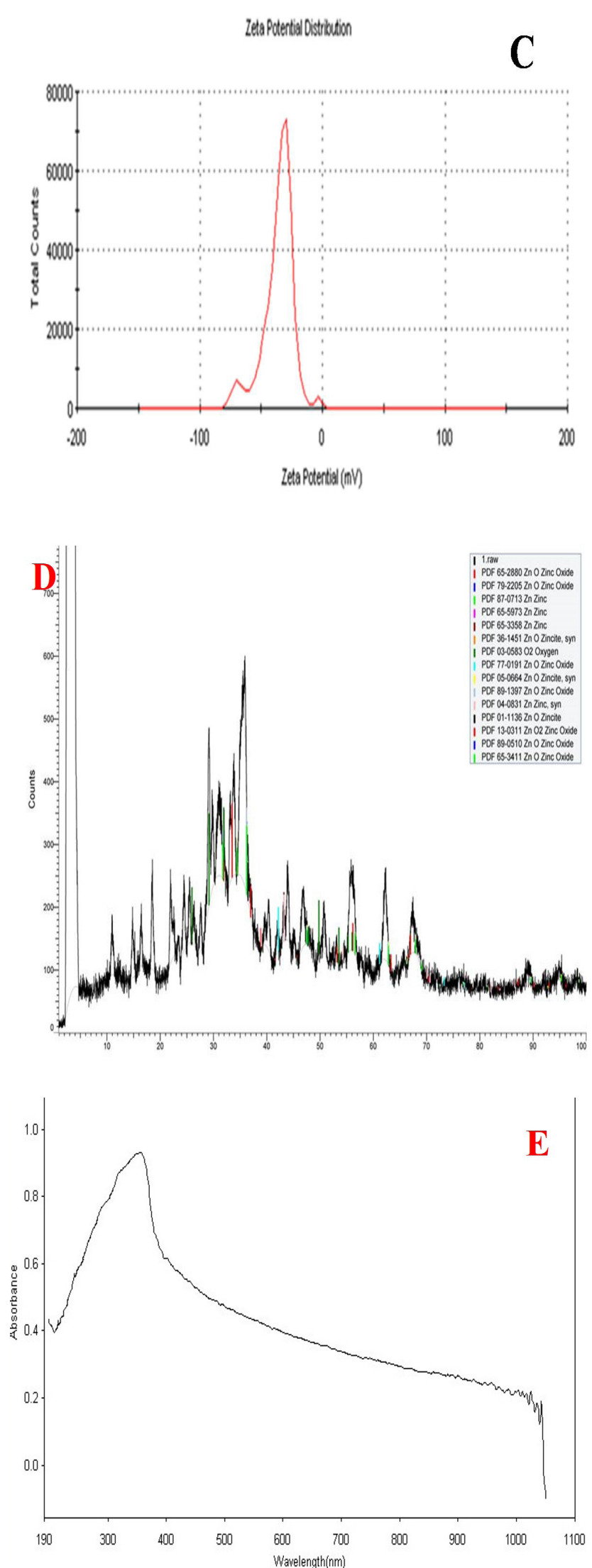

Fig. 1: Characterization of ZnO-NPs. (A) TEM micrograph. Mic. Mag. X 60,000) (B) Histogram of the different nanoparticle sizes (nm). (C) Zeta potentialin $\mathrm{mV}$. (D)X-Ray diffractometer pattern. (E) UV absorbance (nm).

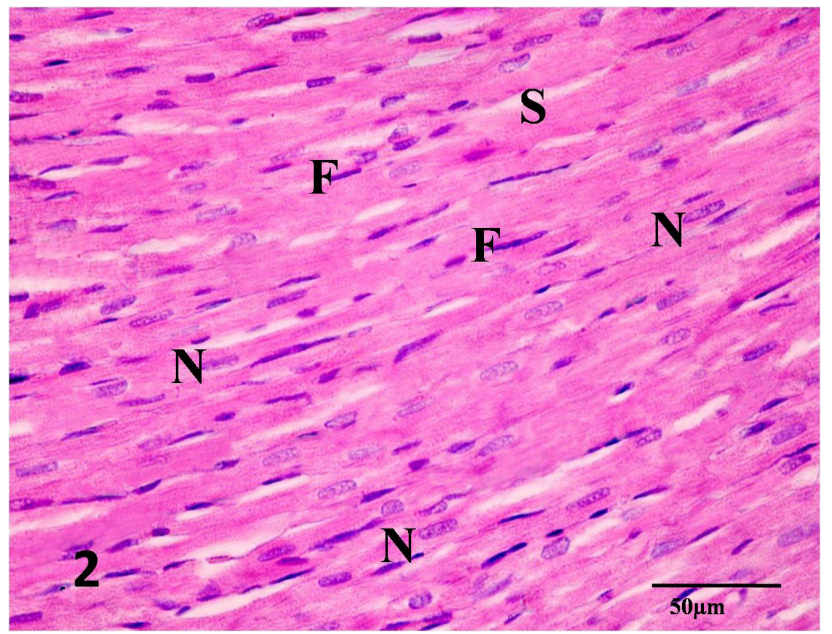

Fig. 2: A photomicrograph of the control group shows branching and anatomizing muscle fibers with narrow interstitial spaces (S). Each cardiomyocyte shows acidophilic sarcoplasm and central oval vesicular nucleus (N). F; Nucleus of interstitial fibroblast. (H\&E Mic. Mag. X 400).

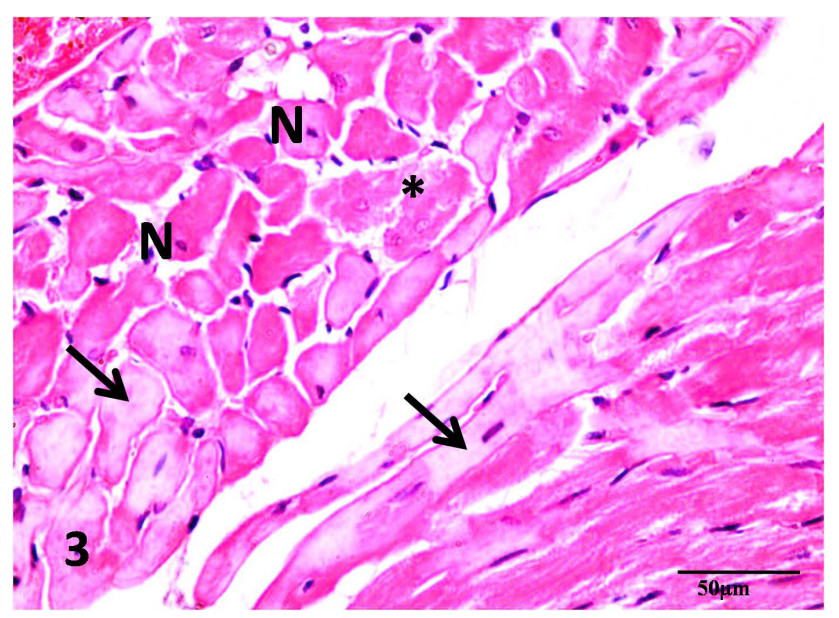

Fig. 3: A photomicrograph of a section of rat left ventricular cardiomyocytes of subgroup IIa showing some muscle fibers with pale stained sarcoplasm and some muscle fibers are fragmented $(*) . \mathrm{N}$; pyknotic nucleus. (H\&E Mic. Mag. X 400).

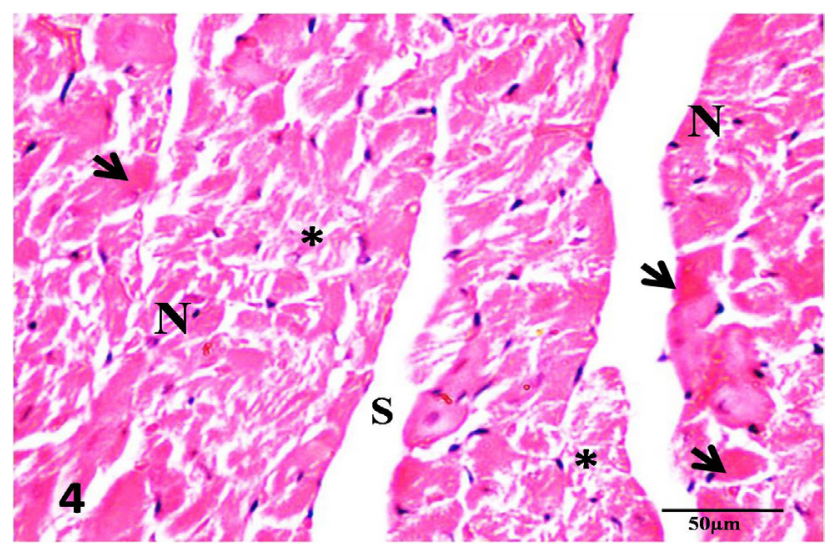

Fig. 4: A photomicrograph of subgroup IIb showing fiber fragmentation (*), hypereosinophilic sarcoplasm (short arrow) and fibers with pyknotic nuclei (N). S; Wide interstitial space. (H\&E Mic. Mag. X 400). 


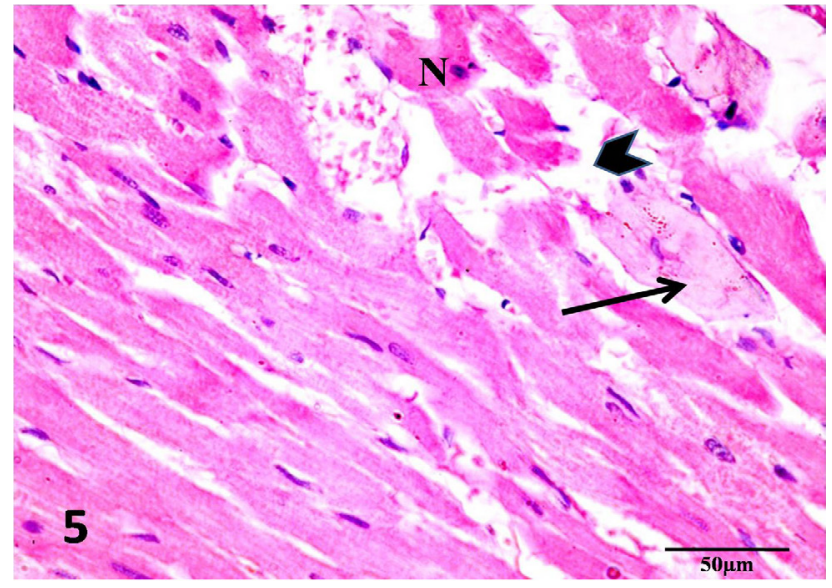

Fig. 5: A photomicrograph of subgroup IIIa showing focal areas of pale acidophilic sarcoplasm (arrow) and interrupted muscle fibers (arrow head). N; pyknotic nuclei. (H\&E Mic. Mag. X 400).

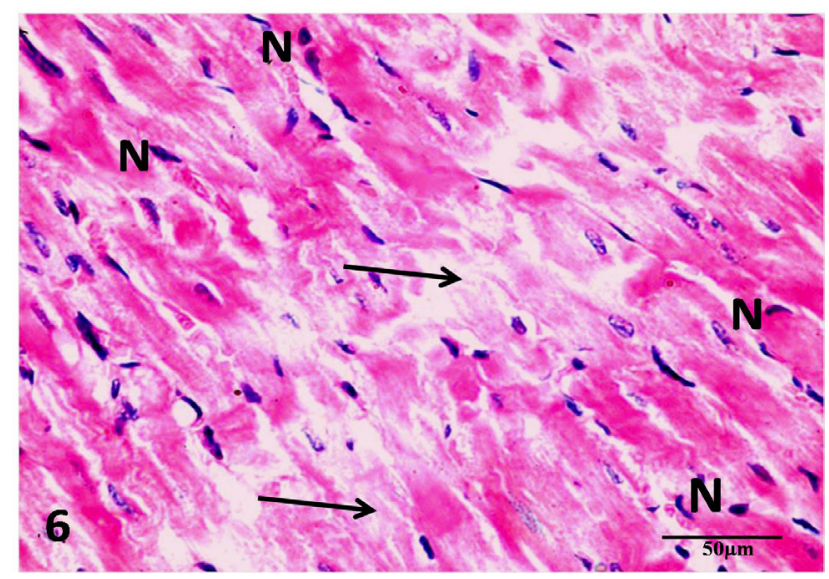

Fig. 6: A photomicrograph of subgroup IIIb showing multiple areas of pale acidophilic sarcoplasm (arrow) and pyknotic nuclei (N). (H\&E Mic. Mag. X 400).

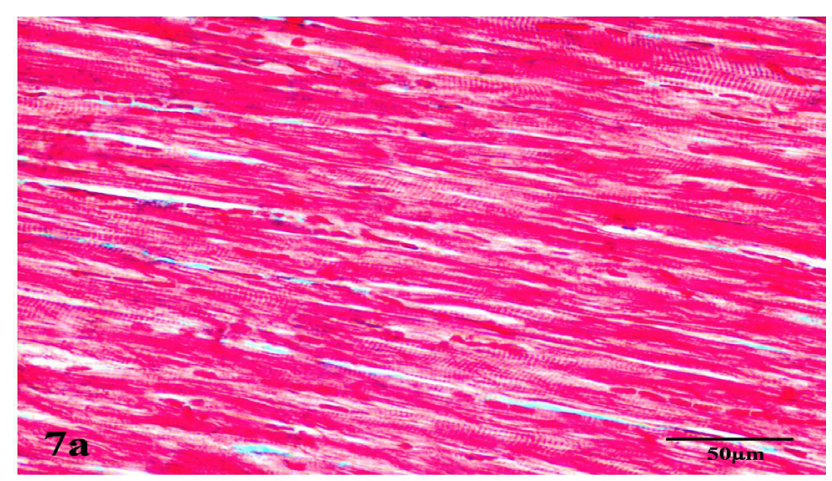

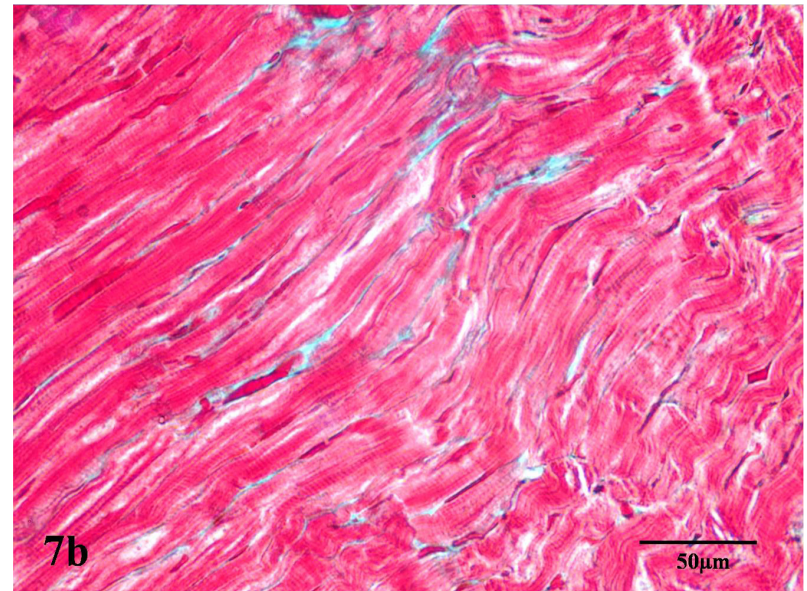
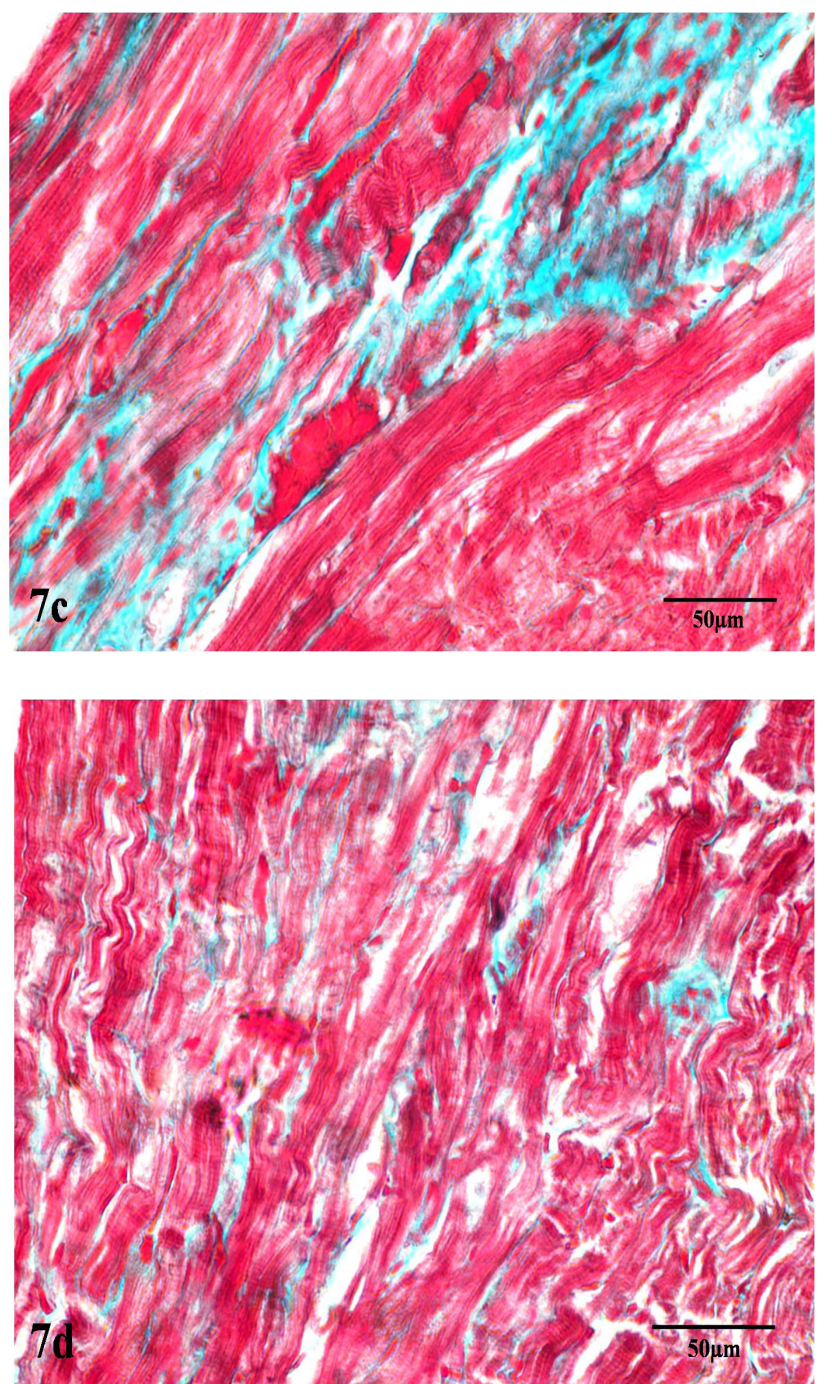


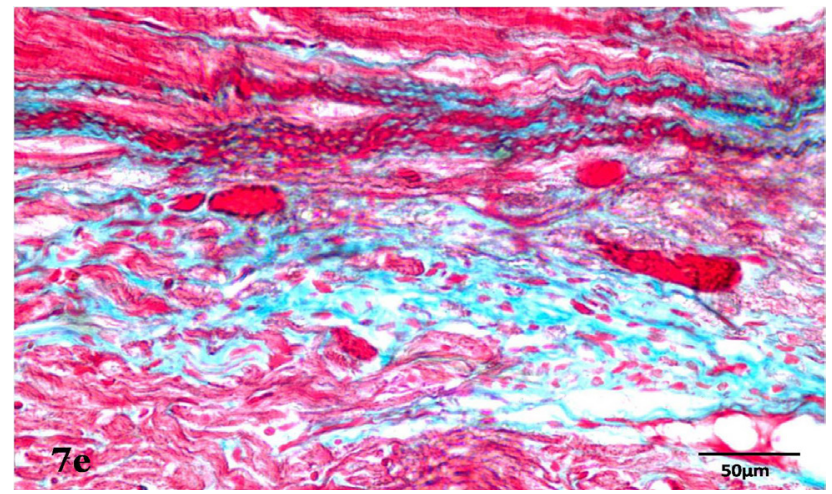

Fig. 7: Photomicrographs of cardiomyocytes, (a) Control group showing scanty collagen fibers. (b) Subgroup IIa, only few interstitial collagen fibers. (c) Subgroup IIb showing considerable amount of collagen fibers. (d) Subgroup IIIa, noticeable amount of collagen fibers is seen. (e) Subgroup IIIb with excessive deposition of collagen fibers. (Masson's Trichrome stain Mic. Mag. X400).

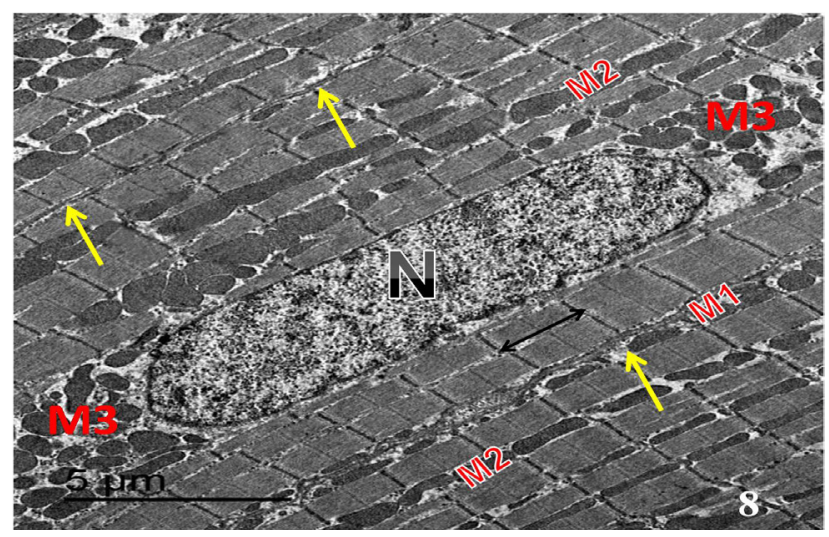

Fig. 8: Electron micrograph of the control group (Ia, Ib) showing parts of three cardiomyocytes with alternating dark and light bands. Sarcomeres are seen between two Z lines (double arrow). The subsarcolemmal (M1) and intermyofibrillar mitochondria (M2) are elongated and regularly aligned in rows, whereas mitochondria at the nuclear poles (M3) are oval or rounded and aggregated in groups. The nucleus $(\mathrm{N})$ is oval central and euchromatic.The sarcolemma of the cardiomyocytes (yellow arrow) appears as a straight line. (Mic.Mag.x1000)

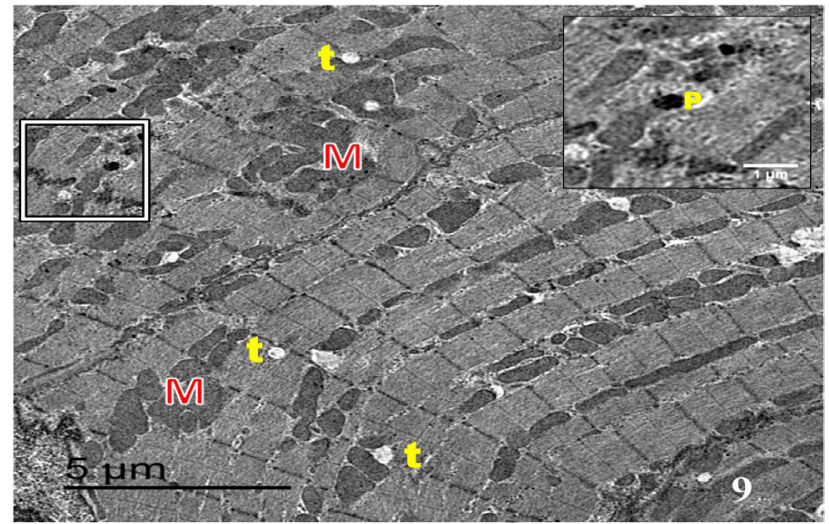

Fig. 9: Electron photomicrograph of subgroup IIa showing parts of three cardiomyocytes. Groups of irregularly arranged intermyofibrillar mitochondria $(\mathrm{M})$ and dilated $\mathrm{t}$ - tubules $(\mathrm{t})$ are seen. Inset; Mitochondrion with electron dense deposits (P) inside. (Mic.Mag.x1000, inset x5000)
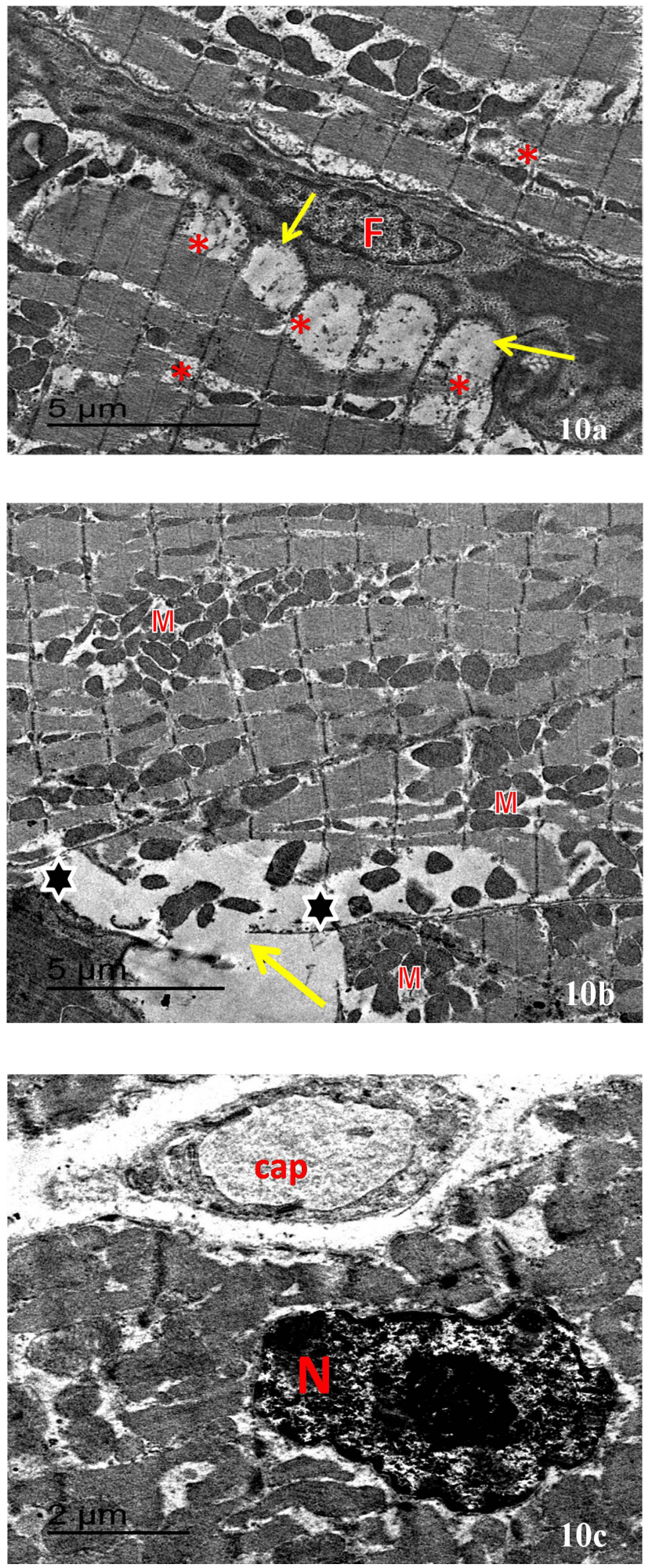

Fig. 10: Electron photomicrograph of subgroup IIb showing (a) parts of two cardiomyocytes with a fibroblast (F) in the interstitial space. Scalloping of the sarcolemma (yellow arrow) and areas of myofibrilla interruption (*) are seen. (b) Disruption of the sarcolemma (yellow arrow), areas of myofibrillar loss ( ) and accumulated groups of mitochondria (M) are seen. (c) Irregular peripheral nucleus $(\mathrm{N})$ with chromatin condensation is depicted. An adjacent blood capillary (cap) is seen. (Mic.Mag. ax1200, b x1000,c x2000) 


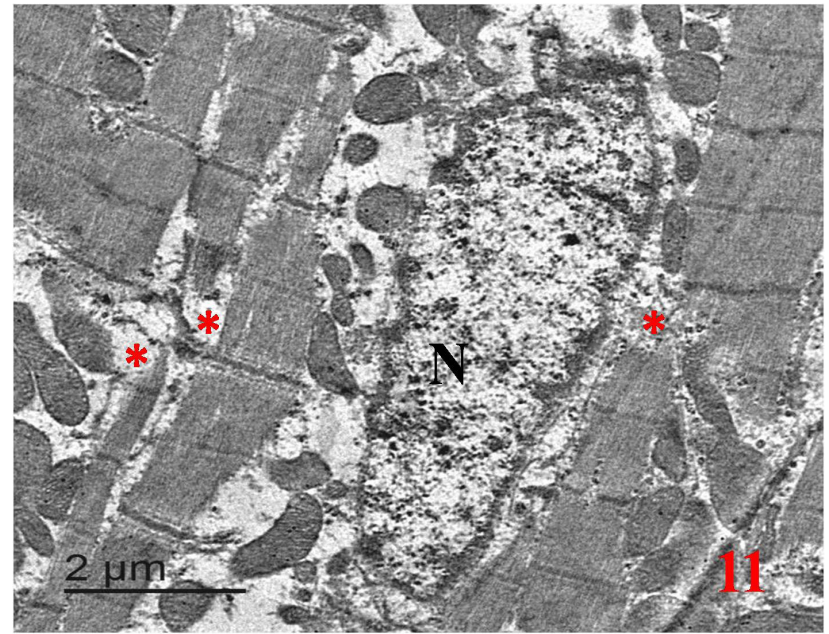

Fig. 11: Electron photomicrographs of subgroup IIIa showing an elongated, euchromatic nucleus $(\mathrm{N})$ and small patches of myofibrillar interruption $(*)$. (Mic.Mag.x2000)
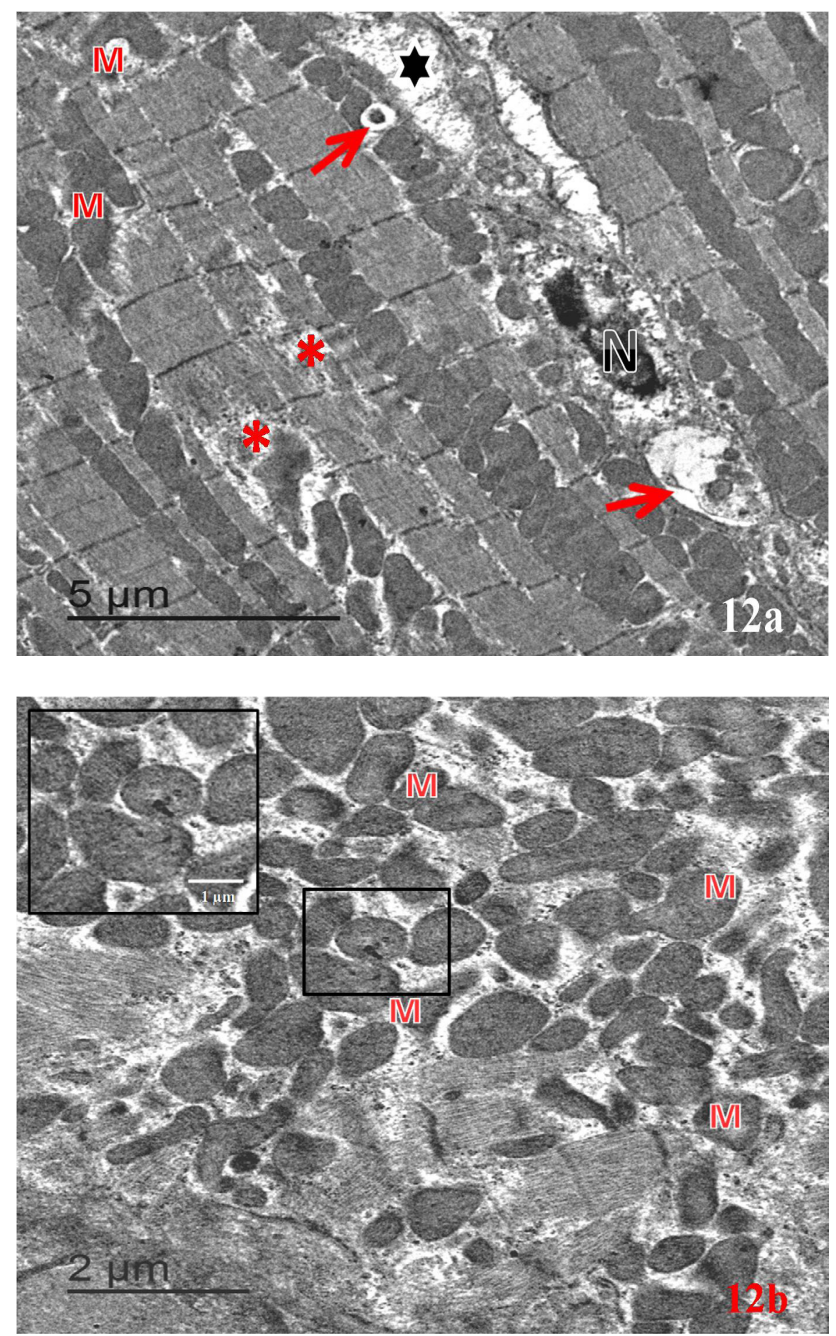

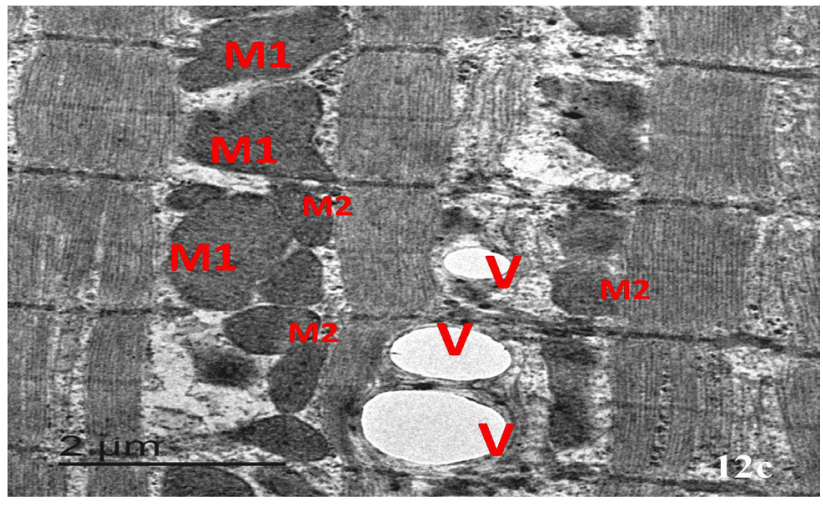

Fig. 12: Electron photomicrographs of subgroup IIIb showing (a) multiple patches of myofibrillar interruption (*) and myofibrillar loss ( ), vacuoles with electron dense material (red arrow) and a shrunken peripheral heterochromatic nucleus. (b) Disorganized myofibrils with the accumulation of large groups of irregularly arranged mitochondria (M) of variable sizes and shapes. Inset shows electron dense particles inside a mitochondrion. (c) Bizarre shaped mitochondria M1 are seen; others appear small and rounded M2. Multiple sarcoplasmic vacuoles (V) of variable sizes are also seen. (Mic.Mag. a x2000, bx 1200, inset x5000, c x2500,)
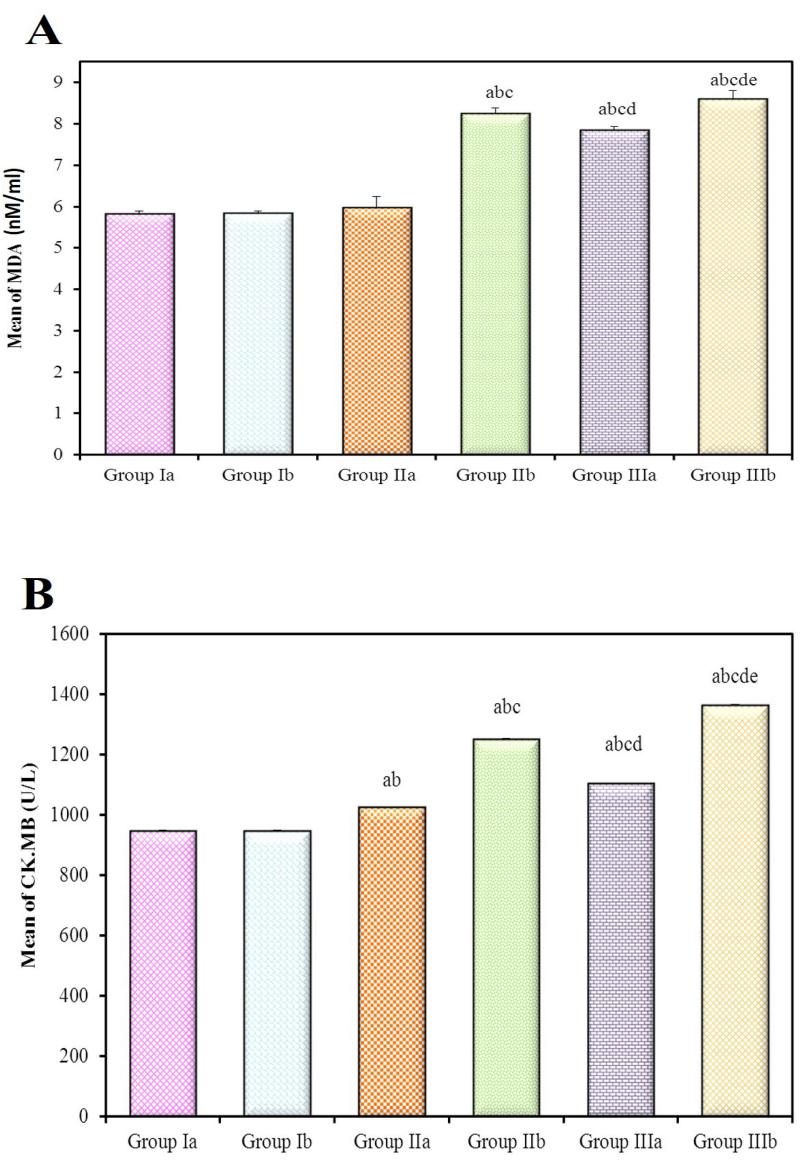

Continued 


\section{C}

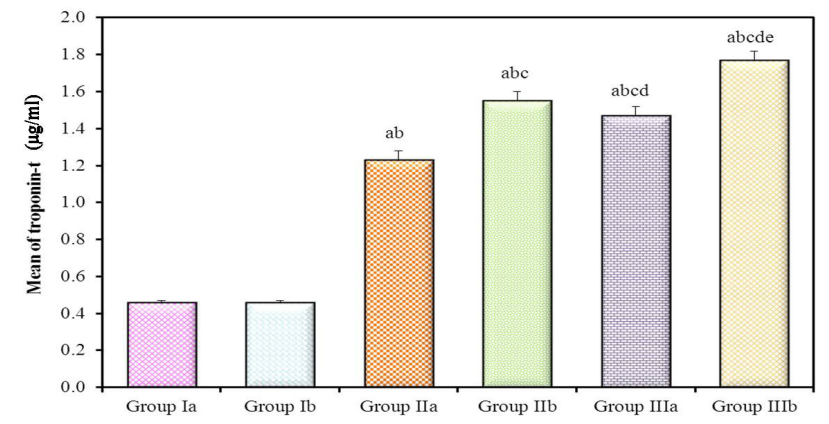

Histogram (A-C): Biochemical studies. (A) Serum MDA levels (nM/ $\mathrm{ml}$ ). (B) Serum creatine kinase-MB (U/L) levels. (C) Serum cardiac troponin- $\mathrm{T}(\mu \mathrm{g} / \mathrm{ml})$. Values represent mean $\pm \mathrm{SD}$. Statistical significance was determined using ANOVA and Post Hoc (Tukey) tests. Different letters are statistically significant at $p \leq 0.05$.

\section{D}

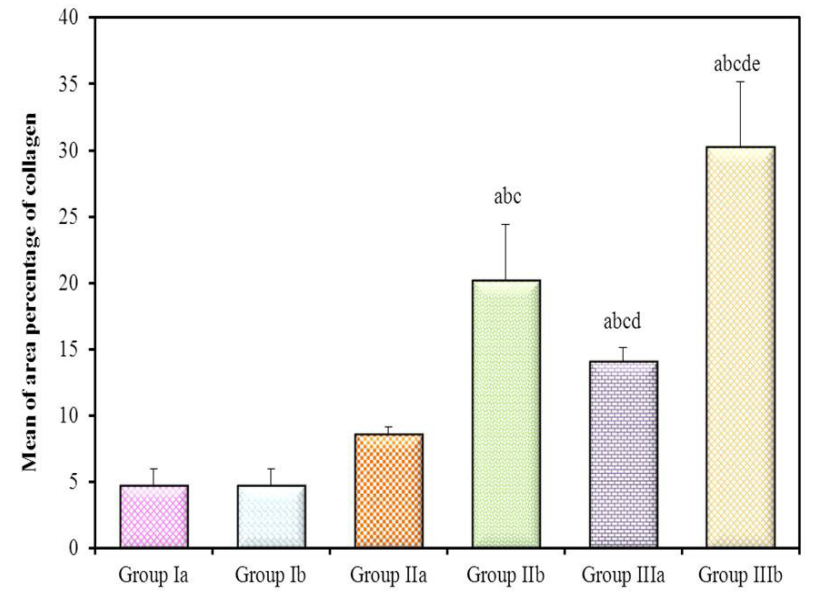

\section{$\mathbf{E}$}

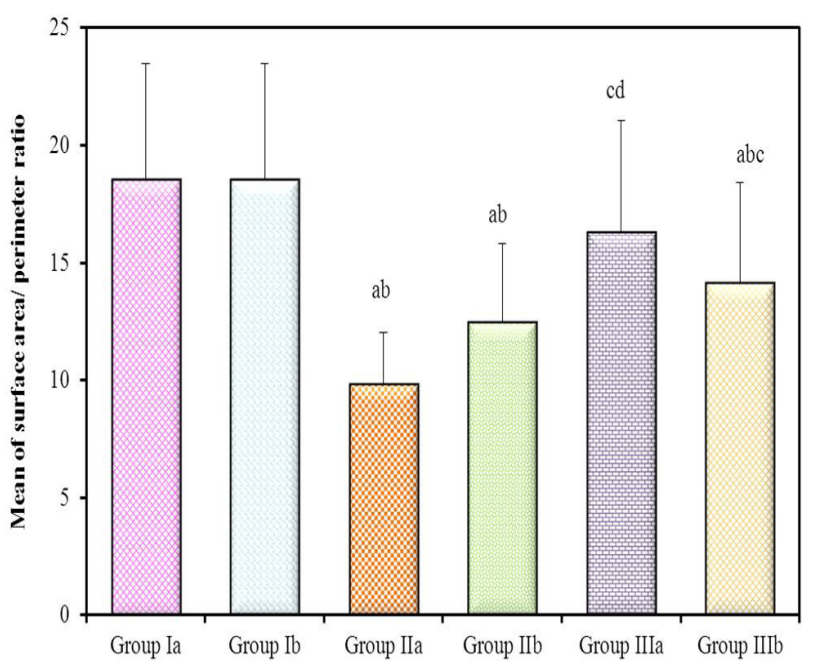

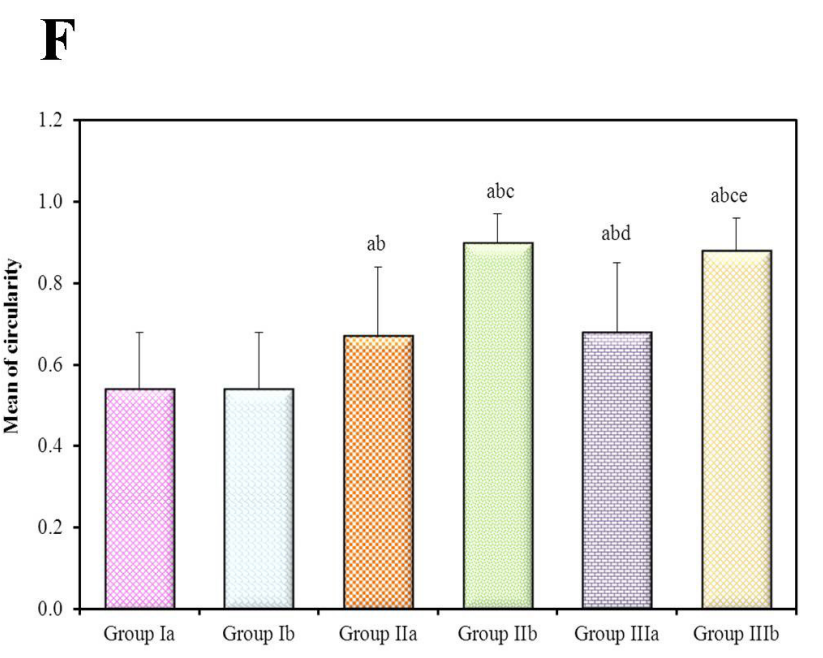

\section{G}

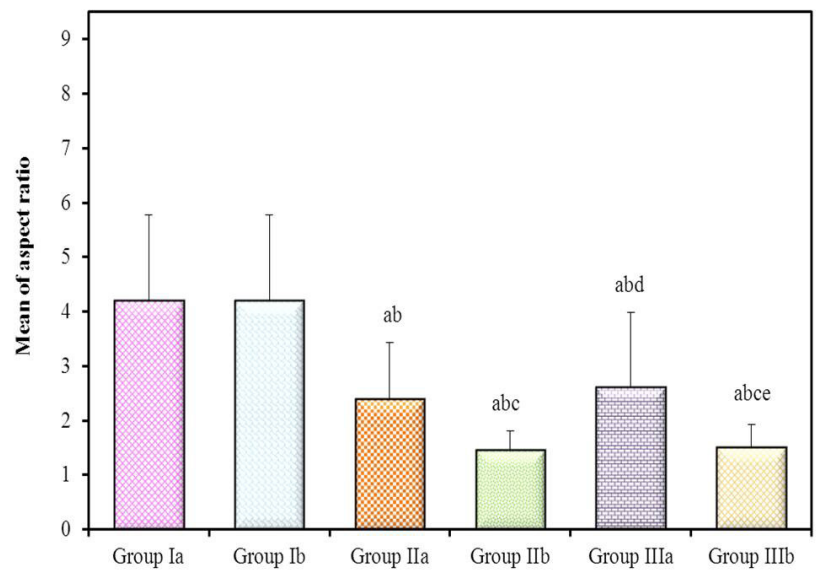

Histogram (D-G): Comparison between the studied groups according to (D) areas percentage of collagen, (E) surface area/perimeter ratio, (F) circularity. Values represent mean \pm SD. Statistical significance was determined using ANOVA and Post Hoc (Tukey). Different letters are statistically significant at $p \leq 0.05$. (G) Aspect ratio. Values represent mean $\pm \mathrm{SD}$. Statistical significance was determined using Kruskal Wallis and Post Hoc (Dunn's multiple comparisons) tests. Different letters are statistically significant at $p \leq 0.05$.

\section{DISCUSSION}

Zinc oxide nanoparticles ( $\mathrm{ZnO}-\mathrm{NPs})$ are known to be one of the most important metal oxide nanomaterials used. It is conceivable that the human body is exposed via several routes. Nevertheless, uptake of NPs from the gastrointestinal tract is the most important route ${ }^{[17]}$. Thus, the present study was undertaken to investigate the oral toxicity of $\mathrm{ZnO}-\mathrm{NPs}$ on the histology of the ventricular cardiomyocytes of adult male albino rats.

In the present study, microscopic examination of treated groups revealed variable myocardial histological changes. At the cellular level, loss of contractile elements that was marked histologically by myocytic fragmentation, 
interrupted muscle fibers and hypereosinophilia which could be attributable in part to increased binding of eosin to the denatured cytoplasmic proteins. It was reported that degeneration of cardiac myocytes occurs due to increased protein degradation and decreased myofibrillar protein synthesis $^{[18,19]}$.

In the current study, ultrastructural examination revealed prominent blebbing and scalloping of the sarcolemma of many cardiomyocytes with areas of sarcolemmal disruption. The sarcolemma is lifted off the myofibrils by edema fluid. Multiple vacuoles were seen and might be attributed to severe myocardial damage with dilated T- tubules. The same was depicted to be associated with cardiomyocyte damage ${ }^{[20]}$.

The mitochondria are the most predominantly affected organelles. It is now evident that all the phenomena that modify mitochondrial morphology can modify cell function ${ }^{[21]}$ Heterogeneity of the size and distribution of cardiac mitochondria usually evidences unbalanced fusion/ fission cycles ${ }^{[22]}$. Particularly, it is common in cases of altered redox status and calcium homeostasis, which were related to an overproduction of reactive oxygen spesies (ROS). Moreover, ROS overproduction is responsible for the so-called ROS-induced ROS release phenomenon, ${ }^{[23]}$ which postulates that excess mitochondrial ROS trigger mitochondrial ROS production in nearby mitochondria. This mitochondrial crosstalk would impact on cardiac cells and leads to apoptosis, necrosis, and even might end by fibrosis ${ }^{[23,24]}$.

Mitochondrial fission/fusion is unfortunately associated with the generation of ROS and induces mitochondrial fragmentation $^{[25,26]}$. The mitochondria might lose their connections to the cytoskeleton-associated with a reduction in their size ${ }^{[27]}$. In the current study, the linear registry of the mitochondria was infrequently seen and they were rather arranged in clusters. This might explain the existence of numerous mitochondria that were irregularly organized in the treated groups.

Generally, the measured parameters of mitochondrial morphology include number, size, and elongation (circularity). Elongation is the best thought of the shape of mitochondria and is a sensitive parameter for fragmentation ${ }^{[28]}$. An example for the importance of measuring multiple parameters for mitochondrial morphology is that the decrease in the number of mitochondria, for example, might not occur because of a loss in mitochondrial biomass, but because most of them are connected to each other and counted as one, large mitochondria ${ }^{[29,30]}$. Therefore, it is recommended for the assessment of mitochondrial morphology to use more than one parameter. At this time, however, it is unknown which parameter is the most important in regards to the health of the cell ${ }^{[29]}$.

The morphometric analysis was in line with the histological study. In group II the surface area/perimeter ratio was significantly lower compared to the control group indicating fragmentation. About the circularity and AR, group II was significantly near to one value compared to the control group indicating that they are less elongated and thus more fragmented. In addition, in subgroup $\mathrm{IIb}$ (given the higher dose) the mitochondria were significantly more fragmented compared to subgroup IIa (given the smaller dose). Importantly, several studies were also able to demonstrate mitochondrial fragmentation in adult rat ventricular cardiomyocyte in response to increased cytosolic $\mathrm{Ca}+2^{[30]}$ and ROS, which are both proved to be the main mechanisms involved in $\mathrm{ZnO}-\mathrm{NPs}$ induced toxicity ${ }^{[2,30]}$.

More changes were detected with the higher dose of $\mathrm{ZnO}-\mathrm{NPs}$ in subgroup IIb. These findings were in agreement with results of previous works. They attributed these changes to oxidative stress $(\mathrm{OS})^{[31-34]}$.

A major OS response is the intracellular calcium $(\mathrm{Ca} 2+)$ release, which leads to mitochondrial $\mathrm{Ca} 2+$ overload causing irreversible cellular damage. Moreover, studies declared that $\mathrm{ZnO}-\mathrm{NPs}$ were shown to induce a significant and sustained increase in $\mathrm{Ca} 2+$ concentration causing changes in membrane potential and mitochondrial dysfunction ${ }^{[35,36]}$.

It has been reported that ZnO-NPs exhibit a dosedependent intracellular accumulation of ROS. As the levels of ROS exceeded the capacity of cellular antioxidants, the antioxidant system could not eliminate them ${ }^{[37,38]}$. This might explain the more severe damage observed in the animals given the higher dose of $\mathrm{ZnO}-\mathrm{NPs}$.

Malondialdehyde (MDA), a marker of lipid peroxidation, was shown to increase significantly after ZnO-NPs administration in a dose-dependent manner ${ }^{[39]}$. Moreover, it has been reported that $\mathrm{ZnO}-\mathrm{NPs}$ at lower concentration induced gene expression of antioxidant defense systems ${ }^{[40]}$. This might explain the less toxic effect on the animals of subgroup IIa that were given the smaller dose associated with the non-significant increase in the serum level of MDA. On the contrary, at a higher dose, these antioxidant defense systems were inhibited ${ }^{[38,41,42]}$. This was documented by the significant increase of serum MDA level in subgroup IIb compared to the control group. Again, this might explain the more toxic effect with the higher dose of $\mathrm{ZnO}-\mathrm{NPs}$ with the statistically significant difference in the serum level of cardiac enzymes in subgroup IIb compared to group I. This confirms the more evident histological changes in the animals given the higher dose.

Nevertheless, the mechanism of ZnO-NPs toxicity was attributed to the combination of more than one phenomenon. Dissolution and release of zinc ions $(\mathrm{Zn} 2+)$ and physical interaction of $\mathrm{ZnO}-\mathrm{NPs}$ were reported also as major mechanisms ${ }^{[43]}$. $\mathrm{Zn} 2+$ at a low concentration is essential for maintaining cellular metabolism; however, at a high level, it shares an essential role in the cellular toxicity of $\mathrm{ZnO}-\mathrm{NPs}^{[44]}$. There are some reports which attributed the toxicity of $\mathrm{ZnO}-\mathrm{NPs}$, to the particles dissolution and 
subsequent release of $\mathrm{Zn} 2+$ intracellularly, leading to ROS mediated cytotoxicity ${ }^{[4]}$. In addition, this rapid $\mathrm{Zn} 2+$ influx results in a rapid decline of mitochondrial membrane potential which subsequently activates the caspasedependent apoptosis. Upon reaching the mitochondria, NPs can generate mitochondrial ROS with disruption of mitochondrial redox state ${ }^{[46,47]}$ causing more elevation of intracellular levels of ROS, cell membrane injury, cell damage and eventually cell death ${ }^{[48,49]}$. This was confirmed by detection of NPs that appeared as accumulated electron dense deposits inside the mitochondria in the current study. From the data, it was declared that the histological changes in the current study might be attributed to the same causes and declared that the higher dose was more damaging to the myocytes.

Another potential mechanism involves the generation of ROS by the NPs themselves and depends on their physicochemical characteristics that lead to the spontaneous generation of ROS at their surface ${ }^{[50]}$. NPs of smaller size induce more OS by disturbing the balance between oxidant and antioxidant processes ${ }^{[51]}$.

In addition, a study demonstrated that $\mathrm{ZnO}-\mathrm{NPs}$ lead to cell death through autophagic vacuole accumulation ${ }^{[52]}$. This was supported in the current study by the appearance of vacuoles containing electron-dense material that might be residual organelles including the mitochondria. Failure to remove the damaged mitochondria might increase cellular damage and the generation of excessive $\operatorname{ROS}^{[52-54]}$.

Meanwhile, data indicated that exposure to $\mathrm{ZnO}$ NPs induces the expression of genes which are involved in apoptosis ${ }^{[55]}$. This was determined by downregulation of B-cell lymphoma 2 (Bcl-2) gene, which protects cardiomyocytes from apoptosis ${ }^{[56]}$. In addition, increased expression of caspase- 3 activity was also observed by some researchers. Apart from inducing apoptosis, activation of caspase-3 was implicated in causing sarcomere disorganization and myofibril disruption. As proved, caspase- 3 can cleave cardiac myofibrillar proteins, such as ventricular myosin light chain, $\alpha$-actin, $\alpha$-actinin and troponin $\mathrm{T}^{[57]}$. Consequently, this might have a direct effect on the reduction of myocyte contractile performance.

As for the interstitium, in the current study collagen fibers deposition was confirmed by the Trichrome stain. The morphometric analysis of the area percentage of collagen fibers was significantly higher in the animals that were given the higher dose. Again, this might reflect the severely damaging effect of the higher dose of $\mathrm{ZnO}-\mathrm{NPs}$. ROS-mediated activation of fibrogenesis is also responsible for the toxicity of $\mathrm{NPs}^{[58]}$. Myocardial injury induces fibroblast proliferation, migration to the injured area, and transdifferentiation into myofibroblasts producing large amounts of interstitial collagen ${ }^{[59,60]}$. In the normal myocardium, fibroblasts are quiescent cells and are responsible only for homeostasis of extracellular matrix (ECM). In the diseased myocardium, fibroblasts are major players of cardiac remodeling, including fibroblast proliferation, migration and increased ECM turnover ${ }^{[61]}$.

The study was further extended to investigate whether a four week withdrawal period would eliminate or improve these histological changes. Unfortunately, it could not reverse the myocardial damage induced by ZnO-NPs administration. In the same line, there was a marked progression of the histological changes in the animals of subgroup IIIb indicating that the myocytes have undergone severe forms of irreversible cell injury. It was previously confirmed that mitochondrial alterations induced by ROS were not totally reversible, especially in the left ventricle ${ }^{[62,63]}$. This goes with the histological, biochemical and the morphometric results in the current study. In the withdrawal group, these changes persisted and even exaggerated reflecting the failure to recover from the injury induced by the administration of $\mathrm{ZnO}-\mathrm{NPs}$ even after the withdrawal period.

\section{CONCLUSIONS}

Thus the current study concluded that oral administration of $\mathrm{ZnO}-\mathrm{NPs}$ is associated with variable microscopic changes in ventricular cardiomyocytes, which are dosedependent. The microscopic changes were accompanied with significant elevation of the oxidative stress marker as well as the cardiac markers. These changes didn't improve after the four-week period of withdrawal.

\section{CONFLICTS OF INTEREST}

There are no conflicts of interest.

\section{REFERENCES}

1. Arora S, Rajwade JM, Paknikar KM Nanotoxicology and in vitro studies: the need of the hour. Toxicol Appl Pharmacol 2012; 258:(2) $151-165$.

2. JolantaPulit-Prociak J, Chwastowski J, Kucharski A, Banach M. Functionalization of textiles with silver and zinc oxide nanoparticles. Appl Surf Sci 2016; 385 (1):543-553.

3. Bumbudsanpharoke N, Choi J, Ko S. Applications of nanomaterials in Food packaging. J Nanosci Nanotechnol 2015; 15:6357-6372.

4. Vlasova MA, Tarasova OS, Riikonen J, Raula $\mathrm{J}$, Lobach AS, Borzykh AA, et al. Injected nanoparticles: The combination of experimental systems to assess cardiovascular adverse effects. Eur J Pharm Biopharm 2014;87:64-72.

5. Pasupuleti S, Alapati S, Ganapathy S, Anumolu G, Pully NR, Prakhya BM. Toxicity of zinc oxide nanoparticles through oral route. Toxicol Ind Health 2012; 28(8): 675-686.

6. Soheili S, Moradhaseli S, Shokouhian A, Ghorbani M. Histopathological effects of $\mathrm{ZnO}$ nanoparticles on liver and heart tissues in wistar rats. Adv Bio Res 2013; 4 (2): 83-88. 
7. El-Morshedi N, Alzahrani I, Nadeem A, Kizilbash, Al-FayezH. Toxic effect of zinc oxide nanoparticles on some organs in experimental male Wister rats. Int J of Adv Res 2014; 2(4):907-915.

8. D'souza D, Subhas BG, Shetty SR, Balan P. Estimation of serum malondialdehyde in potentially malignant disorders and post-antioxidant treated patients: A biochemical study. Contemp Clin Dent 2012;3 (4):448-51.

9. Lygate CA, Bohl S, ten Hove M, Faller KM, Ostrowski PJ, Zervou S, et al. Moderate elevation of intracellular creatine by targeting the creatine transporter protects mice from acute myocardial infarction. Cardiovasc Res 2012;96(3):466-475.

10. Berridge BR, Pettit S, Walker DB, Jaffe AS, Schultze AE, Herman E et al. A translational approach to detecting drug-induced cardiac injury with cardiac troponins: consensus and recommendations from the Cardiac Troponins Biomarker Working Group of the Health and Environmental Sciences Institute. Am Heart J 2009;158 (1):21-9.

11. Aeschbacher S, Schoen T, Bossard M, van der Lely S, Glättli K, Todd J, et al. Relationship Between High-Sensitivity Cardiac Troponin I and Blood Pressure Among Young and Healthy Adults. Am J Hypertens 2014; 28 (6):789-796.

12. Stirling JW, Woods A. Transmission electron microscopy: diagnostic applications. In: Bancroft JD, Gamble M. Theory and Practice of Histological Techniques. $7^{\text {th }}$ ed. London: Churchill Livingstone: 2013; 493 - 538.

13. Bancroft JD, Layton C. The hematoxylins and eosin with Connective tissue and stains. In: Suvarna SK, Layton C, Bancroft JD. editors. Bancroft's theory and practice of histological techniques. Seventh ed., Churchill Livingstone/Elsevier, Philadelphia, 2013: 187-214.

14. Schipke J, Brandenberger C, Rajces A, Manninger M, Alogna A, Post $\mathrm{H}$ et al. Assessment of cardiac fibrosis: a morphometric method comparison for collagen quantification. J Appl Physiol 2017; 122(4):1019-1030.

15. Demeter-Haludka V, Kovács M, Petrus A, Patai R, Muntean DM, Siklós L, Végh A. Examination of the role of mitochondrial morphology and function in the cardioprotective effect of sodium nitrite administered $24 \mathrm{~h}$ before ischemia/reperfusion injury. Front Pharmacol 2018; 9: 286-298.

16. Picard M, White K, Turnbull D. Mitochondrial morphology, topology, and membrane interactions in skeletal muscle: a quantitative three-dimensional electron microscopy study. J Appl Physiol 2013; 114(2):161-171
17. Ben-Slama I, Mrad I, Rihane N, omri K, Elghoul J, El Mir L, et al. Sub-acute oral toxicity of zinc oxide nanoparticles in male rats. J Nanomed Nanotechnol.2015; 6(03): 284.

18. Kumar V, Abbas AK, Aster JC. Robbins basic pathlogy. 9 $^{\text {th }}$ ed. philadelphia: Saunders; 2013: $1-28$.

19. Dubey A, Goswami M, Yadav K, Chaudhary D. Oxidative stress and nano-toxicity induced by $\mathrm{TiO}_{2}$ and $\mathrm{ZnO}$ on WAG Cell Line. PloS One 2015;10 (5): 0127493.

20. Lushnikova EL , Nepomnyashchikh LM, Sviridov EA, Klinnikova MG. Ultrastructural signs of cyclophosphamide-induced damage to cardiomyocytes. Bull Exp Biol Med 2008;146(3):366-371.

21. Wang J.X, Jiao JQ, Li Q, Long B, Wang K, Liu JP, et al. miR-499 regulates mitochondrial dynamics by targeting calcineurin and dynamin-related protein-1. Nat Med 2011; 17: 71-78.

22. Ong SB, Hall AR, Hausenloy DJ. Mitochondrial dynamics in cardiovascular health and disease. Antioxid Redox Signal 2013; 19(4):400-414.

23. Zorov DB, Juhaszova M, Sollott SJ, Mitochondrial reactive oxygen species (ROS) and ROS-induced ROS release. Physiol Rev 2014; ( 3) 94:909-950.

24. Chen YR, Zweier JL. Cardiac mitochondria and reactive oxygen species generation. Circ Res 2014; 114 (3):524-537.

25. Muntean DM, Sturza A, Maria D. Dănilă MD, Borza C, Oana M. Duicu OM, Mornoș C. The Role of mitochondrial reactive oxygen species in cardiovascular injury and protective strategies. Oxidative Med Cell Long 2016; 2016: 1-19.

26. Qian Li, Lu-Yu Zhou, Gui-Feng Gao, Jian-Qin Jiao, Pei-Feng. Mitochondrial network in the heart. Protein Cell 2012; 3(6): 410-418.

27. Gupta A, Gupta S, Young D, Das B, McMahon J, Sen S. Impairment of ultrastructure and cytoskeleton during progression of cardiac hypertrophy to heart failure. Lab Invest 2010; 90:520-530.

28. Wiemerslage L, Le D. Quantification of mitochondrial morphology in neurites of dopaminergic neurons using multiple parameters. J Neurosci Methods 2016; 262: 56-65.

29. Dagda RK, Cherra SJ, Kulich SM, Tandon A, Park D, Chu CT. Loss of PINK1 function promotes mitophagy through effects on oxidative stress and mitochondrial fission. J Biol Chem 2009; 284(20):13843-13855.

30. Hom J, Yu T, Yoon Y, Porter G, Sheu SS. Regulation of mitochondrial fission by intracellular $\mathrm{Ca} 2+$ in 
rat ventricular myocytes. Biochim Biophys Acta 2010; 1797(6-7): 913-921.

31. Okasha E, Ragab M. Histological, Immunohistochemical and ultrastructural study on the effect of gold nanoparticles on the left ventricular cardiac myocytes of adult male albino rat. Middle East J Sci Res 2015; 23 (12): 2968-2982.

32. Xiaohong Yu, Fashui Hong, Yu-Qing Zhang. Bio-effect of nanoparticles in the cardiovascular system. J Biomed Mater Res 2016; (104) 11: 2881-2897.

33. Khanna P, Ong C, Huat Bay B, Hun Baeg G. Nanotoxicity: An interplay of oxidative stress, inflammation, and cell death. Nanomaterials 2015; 5: 1163-1180.

34. Okinen MP, Boyle M, Lieuallen WG, Johnson CL, Malarkey DE, Nyska A. Morphologic aspects of rodent cardiotoxicity in a retrospective evaluation of National Toxicology Program studies. Toxicol Pathol 2011; 39(5): 850-860.

35. Xia, T, Kovochich M, Liong M, Mädler L, Gilbert $\mathrm{B}$, Shi $\mathrm{H}$, et al. Comparison of the mechanism of toxicity of zinc oxide and cerium oxide nanoparticles based on dissolution and oxidative stress properties. ACS Nano 2008; (2): 2121-2134.

36. Carraro M, Bernardi P. Calcium and reactive oxygen species in regulation of the mitochondrial permeability transition and of programmed cell death in yeast. Cell Calcium 2016; 60(2):102-107.

37. Birben E, Sahiner UM, Sackesen C, S, Kalayci O. Oxidative stress and antioxidant defense. World Allergy Organ J 2012; 5(1): 9-19.

38. Saddick S, Afifi M, Abu Zinadaa OA. Effect of zinc nanoparticles on oxidative stress-related genes and antioxidant enzymes activity in the brain of oreochromis niloticus and tilapia zillii. Saudi J Biol Sci 2017;24(7): 1672-1678.

39. El Shemy M, Azab N, Salim R. Zinc oxide nanoparticles: The hidden danger. Inter J Biochem Biophys Mol Biol 2017; 2(1):1-9.

40. Mansouri E, Khorsadi L, Orazizadeh M, Jozi Z. Dose- dependent hepatotoxicity effect of zinc oxide nanoparticles. Nanomed J 2015; 2(4): 273-282.

41. Hao L, Chen L. Oxidative stress responses in different organs of carp (Cyprinus carpio) with exposure to $\mathrm{ZnO}$ nanoparticles. Ecotoxicol Environ Saf 2012;80: 103-110.

42. Saliani M, Jalal R, Goharshadi K. Mechanism of oxidative stress involved in the toxicity of $\mathrm{ZnO}$ nanoparticles against eukaryotic cells. Nanomed J 2016; 3(1): 1-14.
43. Kao YY, Chen YC, Cheng TJ, Chiung YM, Liu PS. Zinc oxide nanoparticles interfere with zinc ion homeostasis to cause cytotoxicity. Toxicol Sci 2012;125(2):462-472.

44. Sirelkhatim A, Mahmud S, Seeni A, et al. Review on zinc oxide nanoparticles: antibacterial activity and toxicity mechanism. Nano-Micro Letters 2015;7(3):219-242.

45. Shrivastava R, Raza S, Yadav A, Kushwaha P, Flora S. Effects of sub-acute exposure to $\mathrm{TiO} 2$, $\mathrm{ZnO}$ and $\mathrm{Al} 2 \mathrm{O} 3$ nanoparticles on oxidative stress and histological changes in mouse liver and brain. Drug Chem Toxicol 2014; 37(3):336-347.

46. Song W, Zhang J, Guo J, Zhang J, Ding F, Li L, et al. Role of the dissolved zinc ion and reactive oxygen species in cytotoxicity of $\mathrm{ZnO}$ nanoparticles. Toxicol Lett 2010;199(3):389-397.

47. Zhao X, Ren X Zhu R, Luo Z, Ren B. Zinc oxide nanoparticles induce oxidative DNA damage and ROS-triggered mitochondria-mediated apoptosis in zebrafish embryos. Aquat Toxicol 2016; 180:56-70.

48. Wang J, Deng X, Zhang F, Chen D, Ding W. ZnO nanoparticle-induced oxidative stress triggers apoptosis by activating JNK signaling pathway in cultured primary astrocytes. Nanoscale Res Lett 2014; 9(1): 1-12.

49. Zhao X, Wang S, Wu Y, You H, Lv L. Acute ZnO nanoparticles exposure induces developmental toxicity, oxidative stress and DNA damage in embryo-larval zebrafish. Aquat Toxicol 2013;136: 49-59.

50. Park SJ, Park YC, Lee SW, Jeong MS, Yu K-N, Jung $\mathrm{H}$, et al. Comparing the toxic mechanism of synthesized zinc oxide nanomaterials by physicochemical characterization and reactive oxygen species properties. Toxicol Lett 2011; 207(3): 197-203.

51. Abbasalipourkabir R, Moradi H, Zarei S, Asadi S, Salehzadeh A, Ghafourikhosroshahi A et al. Toxicity of zinc oxide nanoparticles on adult male Wistar rats. Food ChemToxicol 2015; 84(17): 154160 .

52. Yu K-N, Yoon T-J, Minai-Tehrani A, Kim J-E, Park SJ, Jeong MS, et al. Zinc oxide nanoparticleinduced autophagic cell death and mitochondrial damage via reactive oxygen species generation. Toxicol in Vitro 2013; 27(4): 1187-1195.

53. Iglewski M, Hill J A, Sergio Lavandero S, Beverly A, Rothermel BA. Mitochondrial fission and autophagy in the normal and diseased heart. Curr Hypertens Rep 2010; 12: 418-425.

54. Zabirnyk O, Yezhelyev M, Seleverstov O 
Nanoparticles as a novel class of autophagy activators. Autophagy 2007; 3(3): 278-281.

55. Choudhury SR, Ordaz J, Lo CL, Damayanti NP, Zhou F, Irudayaraj J. ZnO nanoparticles induced reactive oxygen species promotes multimodal cytoand epigenetic toxicity. Toxicol Sci 2017;156(1) :261-274.

56. Baky N, Faddah L, Al-Rasheed N, Fatani A. Induction of inflammation, DNA damage and apoptosis in rat heart after oral exposure to Zinc Oxide nanoparticles and the cardioprotective role of $\alpha$-lipoic acid and vitamin E. Drug Research 2013; 63(5):228-236.

57. Roberge S, Roussel J, Andersson D, Meli A, Vidal B, Blandel $F$ et al. TNF- -mediated caspase- 8 activation induces ROS production and TRPM2 activation in adult ventricular myocytes. Cardiovasc Res 2014; 103(1):90-99.

58. Azad N, Iyer AK, Wang L, Liu Y, Lu Y, Rojanasakul Y. Reactive oxygen species-mediated p38 MAPK regulates carbon nanotube-induced fibrogenic and angiogenic responses. Nanotoxicol 2013;7(2):157-168.
59. Van Nieuwenhoven F, Turner N. The role of cardiac fibroblasts in the transition from inflammation to fibrosis following myocardial infarction. Vascul Pharmacol 2013; 58(3):182-188.

60. Schuetze KB, McKinsey TA, Long CS. Targeting cardiac fibroblasts to treat fibrosis of the heart: focus on HDACs. J Mol Cell Cardiol 2014; 70:100-107.

61. Smiley D, Smith MA, Carreira V, Jiang M, Koch SE, Kelley M, et al. Increased fibrosis and progression to heart failure in MRL mice following ischemia/reperfusion injury. Cardiovasc Pathol 2014;23: 327-334.

62. Nouette-Gaulain K, Biais M, Savineau JP, Marthan R, Mazat JP, Letellier T, et al. Chronic hypoxia-induced alterations in mitochondrial energy metabolism are not reversible in rat heart ventricles. Can J Physiol Pharmacol 2011; 89( 1): 58-66.

63. Ansar S, Abudawood M, Hamed SS, Aleem MM. Exposure to zinc oxide nanoparticles induces neurotoxicity and proinflammatory response: Amelioration by hesperidin. Biol Trace Elem Res 2017;175 (2): 360-366. 


\title{
الملخص العربى
}

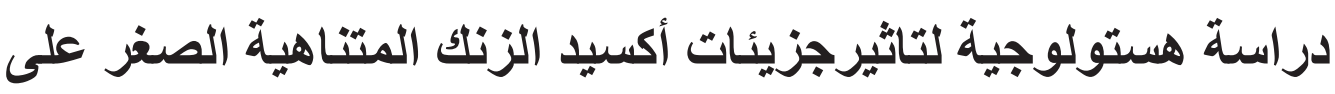

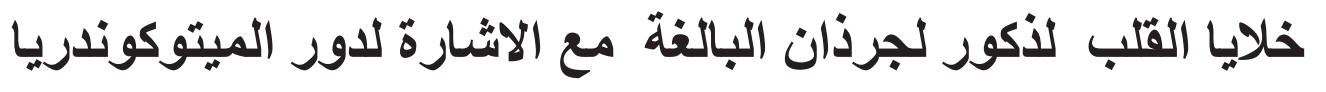

\author{
مشيرة أحمد زهير، أميرة يحيى مدور، أمانى عبد المنعم سليمان، نعمة محمد عبد الفتاح البنوانى \\ قسم الهستولوجيا ـ كلية الطب - جامعة الإسكندرية ـ الإسكندرية امئية
}

المقدمة: جزيئات أكسيد الزنك المتناهية الصغر (ZnO-NPs) هي من بين أكثر الجزيئات المتناهية الصغر شيوعاً وتستخدم في الوقت الحاضر بشكل متز ايد في الغذاء. هذا قد يزيد من فرص تعرض جسم الإنسان عن طريق الفم لتلك الجسيمات ـ القلب و الأوعية الدموية من الاماكن الاكثر عرضه للتاثير السام لتلك الجسيمات النانوية الهدف: كان الهدف من الدراسة الحالية هو التحقيق في التغيرات النسيجية المحتملة التي قد تصاحب إعطاء - ZnO NPs عن طريق الفم في جر عتين مختلفتين على خلايا البطين الأيسر فى الجرذان البيضاءالبالغه. مواد وطرق البحث: أدرج ثمانية وأربعين من الذكور البالغه. تم تقسيم الحيو انات بشكل عشو ائي إلى 3 مجموعات رئيسية. المجموعة الأولى (مجموعة المر اقبة) تم تقسيم المجموعة الثانية (مجموعة ZnO-NP) بشكل عشو ائي إلى

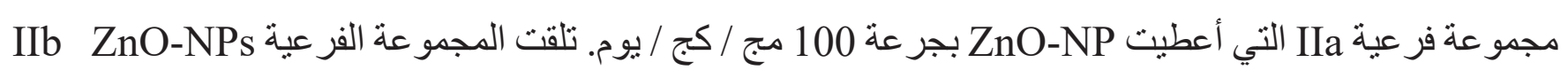

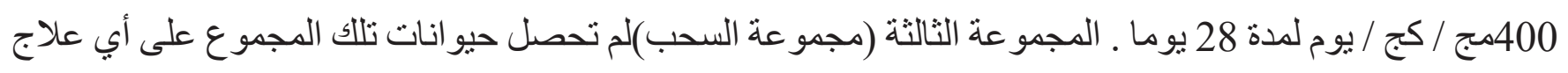
لمدة أربعة أسابيع إضافية بعد 28 بومًا من العلاج. تم تجهيز عينات من قمة القلب للفحص المجهري. تم قياس لعلامات الأكسدة و علامات القلب وكذلك در اسة مورفومترية (لقياس الكو لاجين وقياسات للميتوكوندريا). النتائج: كثف المجهر الضوء و الإلكتروني عن نغير ات نسيجية في عضلة البطين الايسر. التغيير ات كانت تعتمد على الجر عة. المجموعة الثانية، كثفت وجود بهتان في السيتوبلازم وظهرت اخرى لون الصبغه غامقا مع انويه داكنة . و أكد فحص المجهر الإلكتروني هذه التغيير ات وأظهرت تحللا في خلايا القلب و الميتوكوندريا اظهرت تغير في شكلها. و ارتبط هذا معوجود بعض الانويةالداكنة. بعد السحب هذة التغييرات اصبحت أكثر شدة. ارتبط هذا بزيادة ذات دلالة احصائية فى قياسات علامات الاكسده و علامات القلب فى الدم مصاحبه للتغير ات المجهرية. أظهرت قياسات الميتوكوندرياالموفومتربه تكسير. الخلاصة: أظهرت الدر اسة أن ZnO-NP المعطاه عن طريق الفم مرتبطة بتغيير ات مجهرية متعدده ، و هي تعتمد على الجرعة. لم تتحسن هذه التغيير ات بعد ايقاف ZnO-NPs. 